\title{
A comparison of an enzyme-linked immunosorbent assay and counter current electrophoresis for the detection of bovine serum albumin in virus vaccines*
}

\author{
Anja R. ter Avest, $\dagger$ Gijsbert van Steenis $\dagger$ and \\ Albert D. M. E. Osterhaus $\dagger$
}

\begin{abstract}
A monoclonal antibody directed against bovine serum albumin (BSA) has been developed and used in an enzyme-linked immunosorbent assay (ELISA) system for the detection of BSA in virus vaccines. The results correlated well with those obtained with a counter current electrophoresis system which has been employed routinely for this purpose. The ELISA was slightly more sensitive and more readily applicable to the screening of large numbers of samples but could not be used in the presence of certain stabilizers.
\end{abstract}

\section{INTRODUCTION}

The production of many virus vaccines in cell culture is still dependent on the presence of bovine serum in the cell-culture medium. In order to avoid unwanted side effects after vaccination, the presence of non-relevant proteins in virus vaccines, including bovine serum proteins, should be kept to a minimum. According to WHO requirements the amount of bovine serum protein in human vaccines should not exceed $60 \mathrm{ng}$ $\mathrm{ml}^{-1}$ of vaccine. ${ }^{1}$ As bovine serum albumin (BSA) is the major protein present in bovine serum, the total amount of bovine serum proteins may be estimated by determining the BSA content by counter current electrophoresis (CCE) using a rabbit

* Received for publication 7 January 1987.

$\dagger$ National Institute of Public Health and Environmental Hygiene, P.O. Box 1, 3720 BA Bilthoven, The Netherlands. 
antiserum directed against BSA. ${ }^{2}$ However, this method is time consuming and hardly applicable to large numbers of samples. Recently Edevag et al. ${ }^{3}$ described the development of an enzyme-linked immunosorbent assay (ELISA) for ovalbumin determination in influenza vaccines produced in hens' eggs. ${ }^{3}$ We have developed an ELISA which determines BSA content on the basis of the reactivity of the BSA with an anti-BSA monoclonal antibody. A comparison of the results obtained in ELISA and CCE with a series of candidate human and veterinary virus vaccines showed that they coincided well and that ELISA was both more sensitive and more readily applicable to the screening of large numbers of samples. However, the ELISA could not be used for vaccines to which stabilizers, for instance a high concentration of human serum albumin (HSA), has been added.

\section{MATERIALS AND METHODS}

\section{Generation of bybridomas}

Lymphocytes were obtained from the spleens of two BALB/c mice which had been immunized intramuscularly with $0.5 \mathrm{mg}$ of BSA in $0.25 \mathrm{ml}$ of saline (Boseral, Organon, Oss, The Netherlands) emulsified with an equal volume of Freund's complete adjuvant (Difco Laboratories Inc., Detroit, MI). Immunized mice were boosted six weeks later with $0 \cdot 1 \mathrm{mg}$ of BSA in $0 \cdot 1 \mathrm{ml}$ of saline intravenously, 4,3 and 2 days before fusion. Hybridization and cultivation were carried out essentially as described by Köhler and Milstein ${ }^{4}$ with minor modifications. 5

\section{Screening of bybrid cells}

Hybridomas were screened for the production of anti-BSA antibodies by immune fluorescence (IF). For this purpose BSA (fraction V, Calbiochem, San Diego, CA) was labelled with fluorescein-isothiocyanate (FITC) (Isomer I, BBL Microbiological Systems) according to a standard procedure. ${ }^{6}$ About $100-200$ of the hybrid cells from each well were collected and washed three times with phosphate buffered saline (PBS, $\mathrm{pH} 7 \cdot 2)$. Slides of cells were prepared by using a cytospin centrifuge ( $5 \mathrm{~min}, 500 \mathrm{rpm}$ ), dried in an air stream for $10 \mathrm{~min}$, and fixed with ethanol/glacial acetic acid ( $20: 1 \mathrm{v} / \mathrm{v})$ for $15 \mathrm{~min}$ at $-20^{\circ} \mathrm{C}$. The slides were washed twice in PBS and incubated with FITC-labelled BSA preparation for $30 \mathrm{~min}$ at room temperature. The slides were then washed twice again, mounted in glycerol containing $10 \%$ PBS, and examined with a Leitz epifluorescence microscope.

Hybrid cells from positive cultures were single-cell cloned and tested again by the same procedure. Positive subclones were selected and ascitic fluid was raised in BALB/C mice, as described, by the injection of hybridoma cells which had been washed five times with PBS. 5

\section{Characterization, purification and labelling of anti-BSA antibody}

Immunoglobulin was purified from ascitic fluid by Thiophilic adsorption (T-gel) chromatography. ${ }^{7}$ The specificity of the monoclonal antibody for BSA was confirmed by Western blotting. ${ }^{8}$ IgG-isotype was determined using rabbit antisera with heavyand light-chain specificities (Litton Bionetics Inc., Kensington, MD). Purified antiBSA was labelled with horse-radish peroxidase (HRP, type IV, Sigma Chemical Co., St. Louis, MO), according to a modification ${ }^{9}$ of the method previously described by Nakane et al. ${ }^{10}$ 


\section{Vaccines}

Commercial live veterinary virus vaccines were obtained from two different manufacturers. The candidate live attenuated human rubella and measles vaccines had been produced in cell cultures (primary rabbit kidney cells and primary embryo chicken fibroblasts, respectively) by the RIVM. In-process sampling was done after washing and clarification of the bulk suspensions.

\section{Determination of BSA content by means of ELISA}

Serial dilutions of stock BSA preparations obtained from different commercial companies, HSA (HSA, CLB, Amsterdam, The Netherlands) and of sera from different animal species in $0 \cdot 1 \mathrm{M}$ phosphate buffer $(\mathrm{pH} 9 \cdot 1)$ were used in $100 \mu$ l volumes to coat 96-well, flat-bottomed polyvinylchloride ELISA plates (Flow Laboratories, Herts, UK). After incubation for $2 \mathrm{~h}$ at $37^{\circ} \mathrm{C}$ the plates were washed with tapwater containing $0.05 \%$ Tween 80 (Merck-Schuchart, Darmstadt, FRG). To establish a dose-response curve, a 1:3000 dilution of HRP-labelled anti-BSA antibodies containing $0 \cdot 25 \%$ ovalbumin (Grade III, Sigma) and $0.05 \%$ Tween 80 in $100 \mu$ l volumes was added and the plates were incubated for $1 \mathrm{~h}$ at room temperature. After washing the substrate, which consisted of $15 \mathrm{mg}$ of tetramethylbenzidine (TMB, Sigma), $1.6 \mathrm{ml}$ DMSO (Merck) and $10 \mu \mathrm{l} 30 \% \mathrm{H}_{2} \mathrm{O}_{2}$ (in $100 \mathrm{ml}$ of $0.11 \mathrm{M}$ sodium acetate buffer adjusted to $\mathrm{pH} 5.5$ with saturated citric acid), was added. After $10 \mathrm{~min}, \mathrm{H}_{2} \mathrm{SO}_{4}$ was added to a final concentration of $2 \mathrm{M}$ to block the enzymatic reaction. The enzyme activity was determined by measuring the absorbance at $450 \mathrm{~nm}$ after $30 \mathrm{~min}$ on a Titertek reader (Flow Laboratories). The amount of BSA in vaccine preparations was determined in the same manner, but using vaccine instead of BSA solution. A dilution series of bovine serum protein ranging from $0.48 \mu \mathrm{g} \mathrm{ml}^{-1}$ to $7.5 \mathrm{ng} \mathrm{ml}^{-1}$ was used as a standard. Samples were considered positive, and their BSA content estimated, if the mean absorbance values obtained were higher than the mean absorbance value obtained with $60 \mathrm{ng}$ of bovine serum protein per millilitre.

\section{Counter current electropboresis for detecting BSA}

Counter current electrophoresis (CCE) was performed as described by Barme. ${ }^{11}$ To measure the amount of bovine proteins, polyclonal rabbit anti-BSA serum was used at a $1: 4$ dilution. $^{2}$ Serial dilutions to $7.5 \mathrm{ng} \mathrm{ml}^{-1}$ of bovine serum protein were used as a reference. Virus vaccines were diluted serially and the amounts of BSA were determined by Coomassie blue staining.

\section{RESULTS}

\section{Generation and selection of bybridomas}

The fusion of spleen cells from two BALB/c mice immunized with BSA and BALB/C myeloma cells yielded 11 hybridoma cell lines producing anti-BSA antibody as shown by IF using FITC conjugated BSA. One monoclonal antibody B5-16 (IgG $\left.{ }_{1}, K\right)$ was selected on the basis of its more than 1000 -fold higher reactivity with BSA than with HSA. Hybridoma B5-16 was cloned twice at limiting dilution and subsequently passaged as solid or ascitic tumours in BALB/c mice. The antibody was concentrated and affinity purified with T-gel. This monoclonal antibody preparation was found to have about the same reactivity with bovine, ovine and caprine serum albumin and more 
than 1000-fold lower reactivities with serum albumins from pig, dog, cat, rat, mouse and chicken as determined by using sera from these animals in the ELISA system.

The specificity for BSA was confirmed by Western blotting. It reacted exclusively with a $68 \mathrm{Kd}$ protein and not with other bovine serum proteins (not shown), Monoclonal antibody B5-16 was further used for the evaluation of its ability to test virus vaccines for BSA content in the ELISA system.

\section{Comparison of ELISA and CCE}

For a comparison of ELISA and CCE as systems to detect BSA in virus vaccine preparations, 15 samples of human rubella vaccine collected in the process of production (RIVM) and 10 commercially available veterinary live virus vaccines were tested by both assays.

TABLE 1. The determination of the BSA ( $\mathrm{ng} \mathrm{m}^{-1}$ of vaccine) content of human candidate vaccines by ELISA and CCE

\begin{tabular}{crr}
\hline Vaccine samples & ELISA & CCE \\
\hline 1 & 60 & 120 \\
2 & 60 & 60 \\
3 & 960 & 480 \\
4 & 60 & 30 \\
5 & 960 & 480 \\
6 & 60 & 60 \\
7 & 240 & 60 \\
8 & 60 & 60 \\
9 & 60 & 60 \\
10 & 60 & 60 \\
11 & 60 & 60 \\
12 & 240 & 120 \\
13 & 240 & 240 \\
14 & 240 & 120 \\
15 & 240 & 240 \\
\hline
\end{tabular}

TABLE 2. The determination of the BSA content (mg ml${ }^{-1}$ ) of veterinary vaccines by ELISA and CCE

\begin{tabular}{cll}
\hline Vaccine samples & ELISA & CCE \\
\hline 1 & 1.9 & 1.9 \\
2 & 2.4 & 1.9 \\
3 & $4.8 \times 10^{-2}$ & $4.8 \times 10^{-2}$ \\
4 & 1.2 & 0.5 \\
5 & 0.6 & 0.2 \\
6 & 0.6 & 0.1 \\
7 & 0.3 & 0.1 \\
8 & 2.4 & 0.5 \\
9 & 0.5 & 0.4 \\
10 & 0.6 & 0.2 \\
\hline
\end{tabular}


The amounts of BSA found in the human vaccine preparations were $60-960 \mathrm{ng} \mathrm{ml}^{-1}$ by ELISA and 30-480 $\mathrm{ng} \mathrm{ml}^{-1}$ by CCE (Table 1). The amounts of BSA found in the veterinary vaccines ranged from 48 to $2400 \mu \mathrm{g} \mathrm{ml}^{-1}$ by ELISA and from 48 to $1900 \mu \mathrm{g}$ $\mathrm{ml}^{-1}$ by CCE (Table 2). The correlation coefficients $(r$ ) between the results ubtained with both methods were 0.95 for the human preparations and 0.77 for the veterinary vaccines. It can further be concluded that the ELISA is slightly more sensitive.

It was not possible to measure the BSA content with this ELISA of human measles vaccine preparations to which a stabilizer with a relatively high concentration of HSA had been added. ${ }^{12}$ This was due to a minor cross-reactivity of monoclonal antibody B5-16 with HSA. The testing of these preparations by CCE showed that the BSA contents were $\leqslant 60 \mathrm{ng} \mathrm{ml} .^{-1}$ The addition of stabilizing buffers containing sorbitol or gelatin to vaccine preparations also rendered them unsuitable for determination of BSA by ELISA with monoclonal antibody B5-16 (not shown).

Attempts to replace the polycloncal rabbit anti-serum by monocloncal antibody B5-16 in CCE were not successful due to the failure of the monoclonal antibody to precipitate BSA.

\section{DISCUSSION}

In order to develop an alternative to CCE for the measurement of the BSA content of virus vaccine preparations, we generated a monoclonal antibody directed against BSA which could be used in an ELISA system to measure the BSA content. Screening of the hybridomas was performed by a direct fluorescence method demonstrating antibodies in/on hybridoma cells because the presence of BSA in the hybridoma culture medium made it impossible to screen culture fluids for anti-BSA antibodies directly. Only one of the 11 monoclonal antibodies selected (B5-16) was found to have a relatively high specificity for BSA ( $>1000$-fold higher reactivity with BSA than with $\mathrm{HSA}$ ), whereas the others showed high degrees of cross reactivities with HSA. The relatively low cross reactivity of this monoclonal antibody with HSA, however, still rendered it unsuitable for the measurement of the BSA contents of vaccine preparations to which HSA had been added as a stabilizer. Also the addition of other stabilizers such as sorbitol and gelatin interfered with the results of the ELISA with monoclunal antibody B5-16. The difference in correlations observed between CCE and ELISA for human and veterinary vaccines, respectively, may be related to the relatively low grade of purity of the latter. Apart from these drawbacks the relative simplicity and the possibility of testing large numbers of samples in a short time renders the ELISA an excellent tool for use in process control during vaccine production and for the testing of final products for their BSA content. Recently we have shown this ELISA to be suitable for monitoring the removal by immuno affinity chromatography ${ }^{13}$ of bovine serum proteins in the purification of canine parvovirus.

\section{Acknowledgements}

The authors thank Cees Siebelink and Gerben Drost for technical assistance and Ms M. C. Eskens and Ms C. Kruyssen for the preparation of the typescript.

\section{REFERENCES}

1. WHO Technical Report Series 673, Geneva, 1982: 52. 
2. Wezel AL van, Beuvery EC, Hazendonk VAG, Veer $M$ v. d. Kwantitatieve in vitro bepaling van runderserumeiwitten in virusvaccins met behulp van counter current electroforese. Berichten uit het RIV 1976; 201-206.

3. Edevag $G$, Eriksson $M$, Granström $M$. The development and standardization of an ELISA for ovalbumin determination in influenza vaccines. J Biol Stand 1986; 14: 223-230.

4. Köhler G, Milstein C. Continuous cultures of fused cells secreting antibody of predefined specificity. Nature; 256: 495-497.

5. Osterhaus A, UytedeHaag F. Lymphocyte hybridomas: production and use of monoclonal antibodies. Animal Cell Botechnology 1985, 2: 49-69.

6. Hudson L, Hay FC. Pract Immunol 1980: 11-12. London: Blackwell Scientific Publications.

7. Porath J, Maisano F, Belew M. Thiophilic adsorption-a new method for protein fractionation. FEBS Lett 1985; 185: 306-310.

8. Towbin $\mathrm{H}$, Staehelin T, Gordon J. Electrophoretic transfer of proteins from polyacrylamide gels to nitrocellulose sheets: procedure and some applications. Proc Natl Acad Sci USA 1979; 76: 4350-4354.

9. Hagenaars AM, Kuipers AJ, Nagel J. Preparation of enzyme-antibody conjugates. In: Malvano R, ed. Immuno-enzymatic-assay techniques. The Hague: Martinus Nijhoff, 1980: $16-27$.

10. Nakane PK, Kawaoi A. Peroxidase-labelled antibody a new method of conjugation. J Histochem Cytochem 1974; 22: 1084-1091.

11. Barme M. Evaluation de l'ovalbumine par électrosynérèse dans le vaccin antigrippal. Dev Biol Stand 1977; 39: 213-217.

12. McAleer WJ, Markus HZ, McLean AA, Buynak EB, Hilleman MR. Stability on storage at various temperatures of live measles, mumps and rubella virus vaccines in new stabilizer. $J$ Biol Stand 1980; 8: 281-287.

13. Rimmelzwaan GF, Groen J, Juntti N, Teppema JS, UytdeHaag FGCM, Osterhaus ADME. Purification of infectious canine parvovirus from cell culture by affinity chromatography with monoclonal antibodies. J Virol Methods (in press). 